\title{
Welding Competence Training at Dropout Youth
}

\author{
Refdinal, Junil Adri and Purwantono \\ Jurusan Teknik Mesin, Fakultas Teknik, Universitas Negeri Padang, Indonesia
}

\begin{tabular}{l}
\hline Article Info \\
\hline Article history: \\
Received Jan $16^{\text {th }}, 2019$ \\
Revised March $21^{\text {th }}, 2019$ \\
Accepted May $07^{\text {th }}, 2019$ \\
\hline
\end{tabular}

\section{Keywords:}

Community service

Training

Welding Competence

Youth Drop Out of School

Dharmasraya

\begin{abstract}
The problem with partners is drop out youth who do not have competence. The condition of the community dropping out of school and working as unskilled labourers has an impact on the low level of public welfare. The distance between the Dharmasraya district and the provincial capital has an impact on the contrast of the quality of education carried out which causes the community to not understand the importance of education. So that some of the human resources in Dharmasraya have become manual labourers in plantations and factories. The purpose of implementing this service activity is to provide a solution to the problems faced by the community, especially for school dropouts. Most of the dropout youths who are junior high school (SMP) level do not have special competencies that make them have added value. The work carried out by this young man is only limited to gardening and does not guarantee economic prosperity. Through this service activity, TIM strives to provide competency in the welding field that can be used to open a business that is much needed by the community. The training activities were designed for 3 days which will be held from October 12 to October 14 2018. The speakers in this activity were Drs. Purwantono, M.Pd, who has a BNSP level I welding certificate and the second speaker is Junil Adri, M.Pd.T who has a BNSP level III welding certificate. On the first day, the speaker will convey the basic concepts in the welding process and demonstrate how to make weld grooves and connect the plate in the welding process. On the second day, the speakers began to invite participants to design products that could be made through welding activities in accordance with the needs of the community. In this activity, TIM directed to make a trellis fence. TEAM began to guide participants in the process of making a trellis. On the third day, the TEAM provided direction on how to weld entrepreneurial opportunities in the field. The chairperson of the service with TIM asked the kenagarian to be able to accommodate the birth of new entrepreneurs for youth who could make independent and productive people.
\end{abstract}

Corresponding Author:

Junil Ardi,

Jurusan Teknik Mesin, Fakultas Teknik, Universitas Negeri Padang

Jln. Prof. Dr Hamka Air Tawar, Padang (25131), Sumatera Barat, Indonesia

Email: juniladri@gmail.com

\section{INTRODUCTION}

Improving the quality of human resources to achieve national goals, such as those contained in GBHN, is needed by educated people who have life skills that can help them in their lives in the midst of society. For this reason, education and skills must be given to the younger generation. The planning and development of the younger generation should be adjusted to the needs of the workforce and the opportunities and employment available then an effective system that can support it. Today we see a lot of young people dropping out of school due to the inability of parents to finance their children's education. Dropping out of school is the process of forced cessation of a student from an educational institution where he is studying. The meaning is the neglect of children from a formal education institution, which is caused by various factors, one of which is an inadequate family economic condition [1]. Even though "children are human beings who will continue the ideals of their parents and as a relay for the future" [2]. Children are the next generation for the survival of the family, nation and state in the future. Therefore it guarantees the next generation to be able to grow and develop well is a future social investment that is not cheap and must be borne by family, society and the state [3].

Dropping out of school is not a new problem in the history of education. Economic factors are important reasons for dropping out of school. This issue has its roots and is difficult to solve because when 
discussing solutions there is no choice but to improve the family's economic conditions. When discussing family economic improvement related to how to increase human resources. While all the desired solutions will not be separated from the national economic conditions as a whole so that government policies play an important role in overcoming all problems including improving the condition of society [4]. The government has tried to overcome the problem of dropping out of school by providing the School Operational Assistance Program (BOS). The aim of this program is to free up the cost of education for students who are not able and reduce other students so that they can get better quality basic education services until they finish in order to complete the 9-year compulsory education. Although efforts have been made by the government cases of dropping out of school still remain.

Various studies in Bali and Jambi state several factors that affect dropouts, namely: economic status, type of student education (general or vocational), pregnancy, poverty, discomfort, student delinquency, illness, interests, traditions / customs, parental education, the work of parents, the age of the parents, the number of family dependents, the conditions of residence and the attention of parents [5]. Based on the research [6], it was stated that the dropout rate was caused by the limited number of schools available, social / community factors, per capita expenditure in a region, and the number of children in the family. Based on the above theories, it can be stated that the causes of elementary school dropouts referred to in this study are: economic factors, geography, the number of siblings, no electricity lighting, low parental education and socio-cultural factors. While the causes of school dropouts are the number of teachers, literacy rates, poverty levels, and the level of employment opportunities that are owned by a region [7].

The fact that 8 million students are at risk of dropping out of school is delivered by A Piet Simandjuntak, Secretary of the Management of the Foster Parents National Movement (GN-OTA). The high number of school dropouts is suspected to be the base of many cases of exploitation of minors, trafficking in children (trafficking), and drugs [8]. Unemployment has also spread to various regions in Indonesia. [9] The unemployment rate in Indonesia is the highest among ASEAN countries. The Minister of Manpower and Transmigration (Depnakertrans) estimates that potential candidates for unemployment will experience an increase of 2.5 million people, namely from the new workforce of 2.3 million people plus victims of natural disasters of around 200 thousand people. According to Erman Suparno (2012) currently, there are 10.9 million unemployed people. To overcome this condition, the Ministry of Manpower and Transmigration will focus on increasing the movement of entrepreneurship in rural and urban poor communities, namely through training, certification and job placement programs.

The limited available employment is not balanced with the number of workforces that is increasing every year which has an impact on the high number of unemployed. When viewed according to age group, out of the 10.9 million unemployed in 2016, most of the 5.6 million (60\%) were unemployed young people aged 15-24 years. Of the 5.6 million unemployed youth, 3 million unemployed aged 20-24 years and 2.6 million youth aged 15-19 years. With a composition of 2.88 million living in cities, and as many as 2.8 million living in rural areas. The distribution of unemployed youth according to a place of residence differs according to age group. Unemployed youth aged 15-19 years more in the countryside (1.5 million people) than in urban areas (1.1 million people). Whereas unemployed youth aged 20-24 years are more in urban areas (1.78 million people) than in rural areas (1.27 million people). In West Sumatra, according to the Central Statistics Agency (BPS), in the first quarter of 2017, the number of unemployed people in West Sumatra amounted to 206,740 people or a decrease of 10,565 people $(4.86 \%)$ from 2007 which amounted to 217,305 people. From the figures above, although there is a tendency for a lack of unemployment rates, it still shows a number that concerns us all. The biggest increase occurred in the agricultural sector (50 per cent), trade (20.9 per cent) and services (12.2 per cent). In West Sumatra, according to the Central Statistics Agency (BPS), the first quarter of 2017 unemployed people in West Sumatra amounted to 206,740 people decreased from 10,565 people (4.86\%) from 2007 which amounted to 217,305 people. From the figures above, although there is a tendency for a lack of unemployment rates, it still shows a number that concerns us all. The biggest agricultural sector (50 per cent), trade (20.9 per cent) and services (12.2 per cent).

Youth are individuals who when viewed physically are experiencing development and psychologically are experiencing emotional development. Youth is Indonesia's human resources that will fill development both now and later, as future generations of candidates who will replace the previous generation. The limit for defining youth is based on age, namely 15-24 years. In general, the age limit of youth in each country is not the same, but according to the United Nations Agency in charge of health (WHO); refer to youth as 'young people' with the age limit of 10-24 years, while the age of 10-19 years is called 'adolescence' or teenager.

Through this community service activity, the dedication team was determined to provide guidance on welding competencies to school dropouts in the wilderness of Koto Padang. The design of activities made on the achievements of school dropouts is able to weld and make products on welding skills such as bars and fences. This young man will also be provided with entrepreneurial insight into the potential of the welding

Journal homepage: http://teknomekanik.ppj.unp.ac.id

DOI: https://doi.org/10.24036/tm.v2i2.2372 
field. The hope of the dedication team with this activity is to be able to reduce the digging rate in Dharmasraya and be able to give birth to new entrepreneurs. The purpose of implementing this service activity is to provide a solution to the problems faced by the community, especially for school dropouts. Most of the dropout youths who are junior high school (SMP) level do not have special competencies that make them have added value. The work carried out by this young man is only limited to gardening and does not guarantee economic prosperity. Through this service activity, TIM strives to provide competency in the welding field that can be used to open a business that is much needed by the community. The benefits obtained in this service activity are the implementation of the obligation of the tri dharma of the high ranking of the service team and the help of the youth in becoming independent and productive individuals.

\section{METHOD}

The method of applying science and technology carried out in this activity is in accordance with the schematic problem-solving framework. Problems arise due to various factors, the target audience is the younger generation dropping out of school. In accordance with the objectives to be achieved in this activity is to produce skilled young people who are at the same time have the motivation to entrepreneurship, the method applied is to provide direct training to the younger generation to carry out various kinds of welding techniques. The following is a schematic problem-solving framework and its relationship with the target audience.

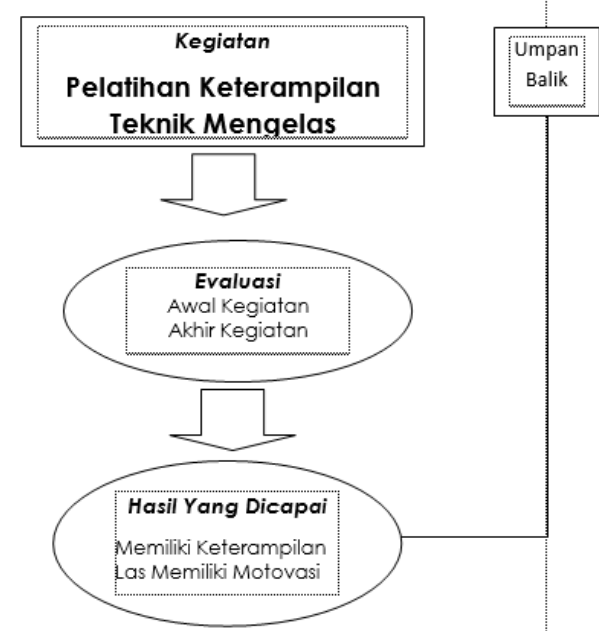

Fig. 1. Schematic problem-solving framework and its relationship with the target audience

This training activity was prepared by two mechanical engineering lecturers who already had welding certification. The programs that will be carried out are as follows:

Table 1. Composition of Training Activities

\begin{tabular}{|c|c|c|c|}
\hline No & Description of activities & Time & Facilitator \\
\hline I & $\begin{array}{l}\text { Survey to the location to record the number of } \\
\text { drop-out youths in the village }\end{array}$ & 8 hours & $\begin{array}{l}\text { Service Team } \\
\text { Community and students }\end{array}$ \\
\hline II & $\begin{aligned} & \text { Implementation of Activities } \\
& \text { 1. } \text { Motivation } \\
& \text { 2. } \text { Introduction of tools } \\
& \text { 3. } \text { Welding process } \\
& \text { 4. } \text { Demonstration } \\
& \text { 5. } \text { Discussion }\end{aligned}$ & 8 hours & \\
\hline III & $\begin{array}{l}\text { Practice Welding } \\
\text { 1. Turn on the arc on } \\
\text { 2. Welding various connections } \\
\text { 3. Application of welding processes in the } \\
\text { field }\end{array}$ & 40 Hours & \\
\hline
\end{tabular}

\section{RESULTS}

Journal homepage: http://teknomekanik.ppj.unp.ac.id

DOI: https://doi.org/10.24036/tm.v2i2.2372 


\subsection{Activity Planning Process}

This training activity on welding competence requires careful planning. Considering and considering the target audience of this training is that young people drop out of school, the TEAM formulates the method to be implemented in this activity which is demonstration and implementation of product results that can be made through welding activities. To support the basic knowledge of the target audience TIM made a module that discussed basic material about welding. With the help of this module, participants are expected to be able to quickly understand the basic concepts of welding. The form of modules made to support activities can be seen in the appendix. The training activities were designed for 4 days which will be held from October 11 to October 14 2018. The speakers in this activity were Drs. Purwantono, M.Pd, who has a BNSP level I welding certificate and the second speaker is Junil Adri, M.Pd.T who has a BNSP level III welding certificate. On the first day, the speaker will convey the basic concepts in the welding process and demonstrate how to make weld grooves and connect the plate in the welding process. On the second day, the speakers began to invite participants to design products that could be made through welding activities in accordance with the needs of the community. In this activity, TIM directed to make a trellis fence. On the third day, the TEAM began to guide participants in the process of making trellises. On the fourth day, the TEAM provided direction on how to welding entrepreneurial opportunities. The head of the service with TIM asked the kenagarian to be able to accommodate the birth of new entrepreneurs for youth who could make independent and productive people.

\subsection{Implementation Results}

The realization of service to the community has been carried out welding competency training for school dropouts in Kenagarian Koto Padang, Koto Baru District, Dharmasraya Regency. This realization was carried out on 11-14 October 2018. The handover of welding competency training was held on 11 October 2018. Welding competency training was conducted on 12-14 October 2018. The speakers in this activity were Drs. Purwantono, M.Pd, who has a BNSP level I welding certificate and the second speaker is Junil Adri, M.Pd.T who has a BNSP level III welding certificate. This welding competency training was also assisted by four students from the Mechanical Engineering Department, Faculty of Engineering, Padang State University.

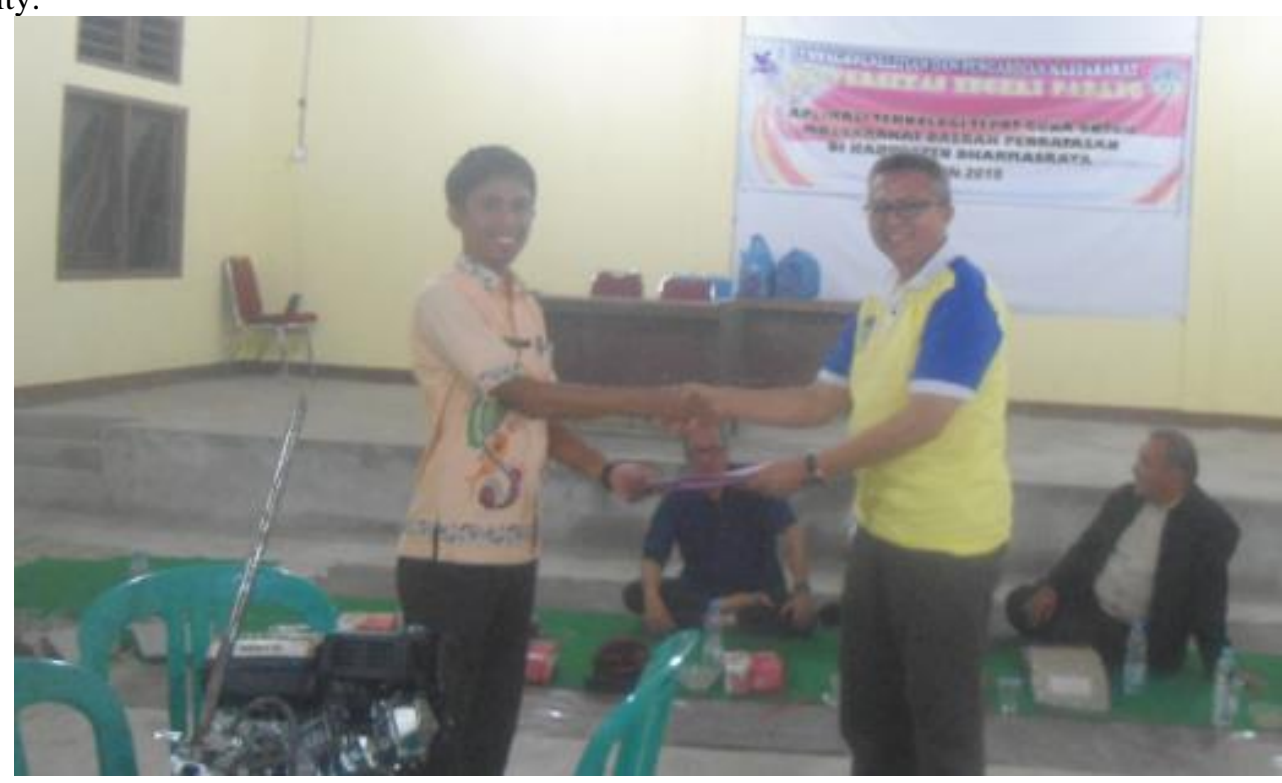

Fig. 2. Handover of community service in the form of welding competency training. 


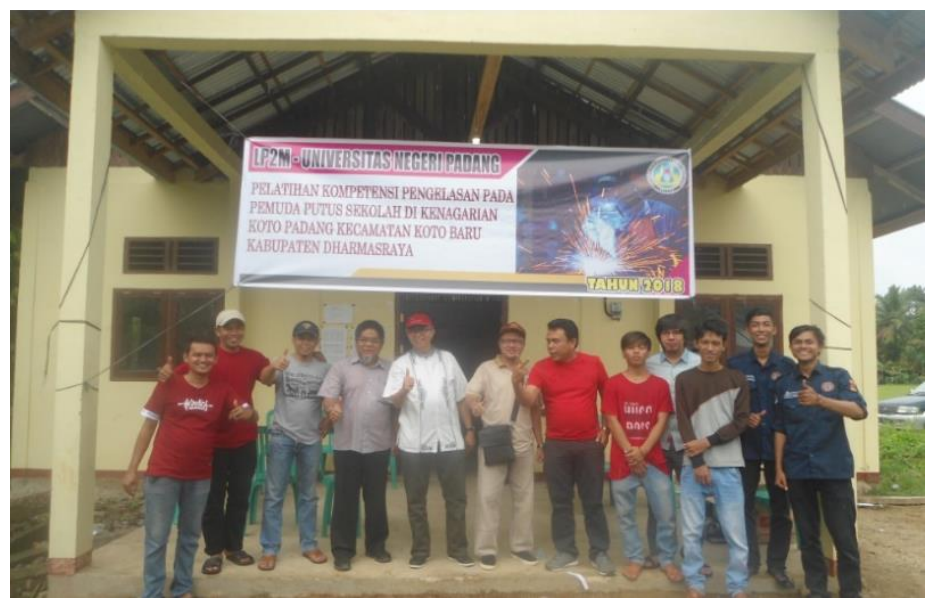

Fig. 3. The first day of welding competency training.

The first day of the welding competency training on October 12, 2018, was the first to be carried out namely to increase the electric power from 900 watts to 4500 watts. After the electric power is increased, the lecturers, students and adolescents who take part in the training gather and the lecturer distribute the welding module to the welding participants while one of the lecturers (Drs. Purwantono, M.Pd) gives a briefing on the tools to be used in the training. Drs. Purwantono, M.Pd also teaches basic welding techniques to teenagers. Drs. Purwantono, M.Pd also immediately gave a direct example of how to conduct welding on the media. After being given an example by the lecturer, one by one the teenagers who participated in the training were asked to practice the basic welding techniques.

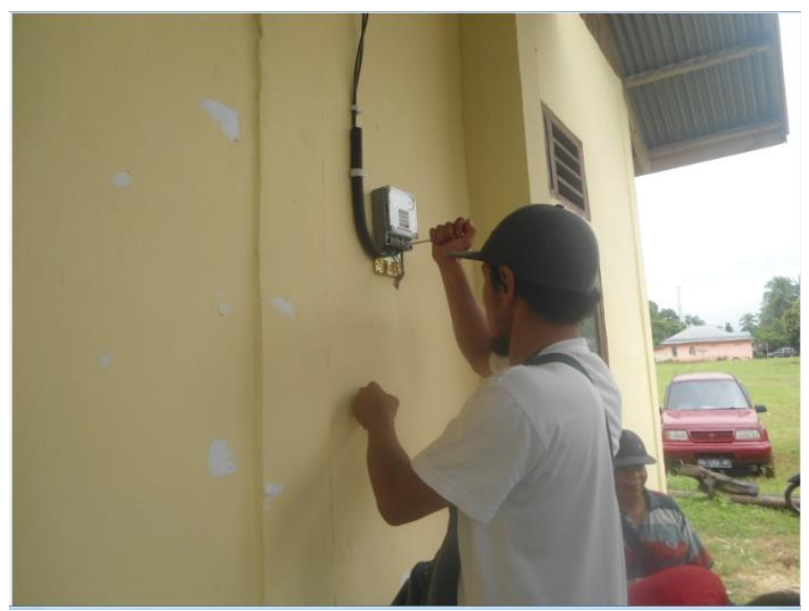

Fig. 4. Increasing Electricity from 900 Watts to 4500 Watts

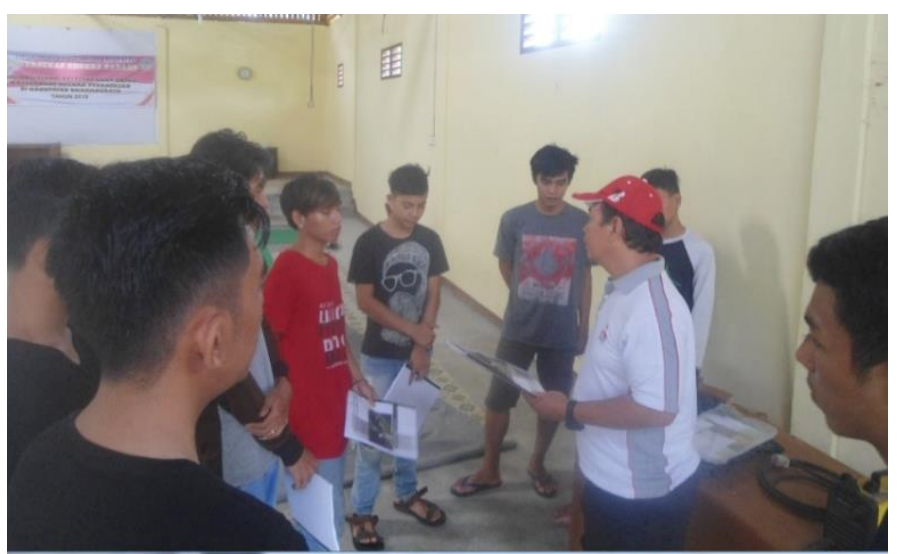

Fig. 5. Distribution of Welding Modules to Participants 


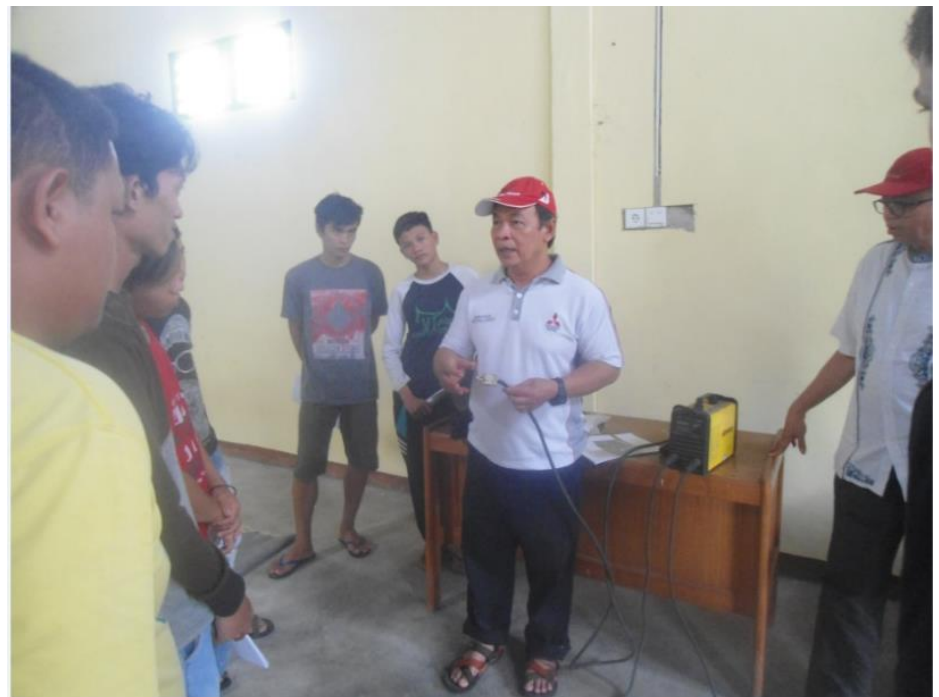

Fig. 6. One of the lecturers gave a briefing on welding tools

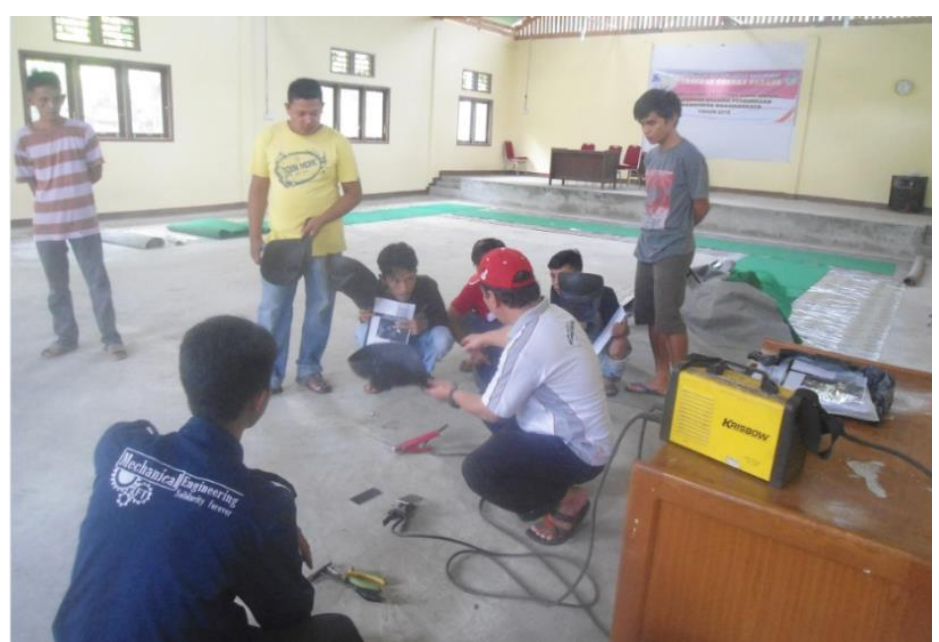

Fig. 7. The lecturer provides guidance on basic welding techniques

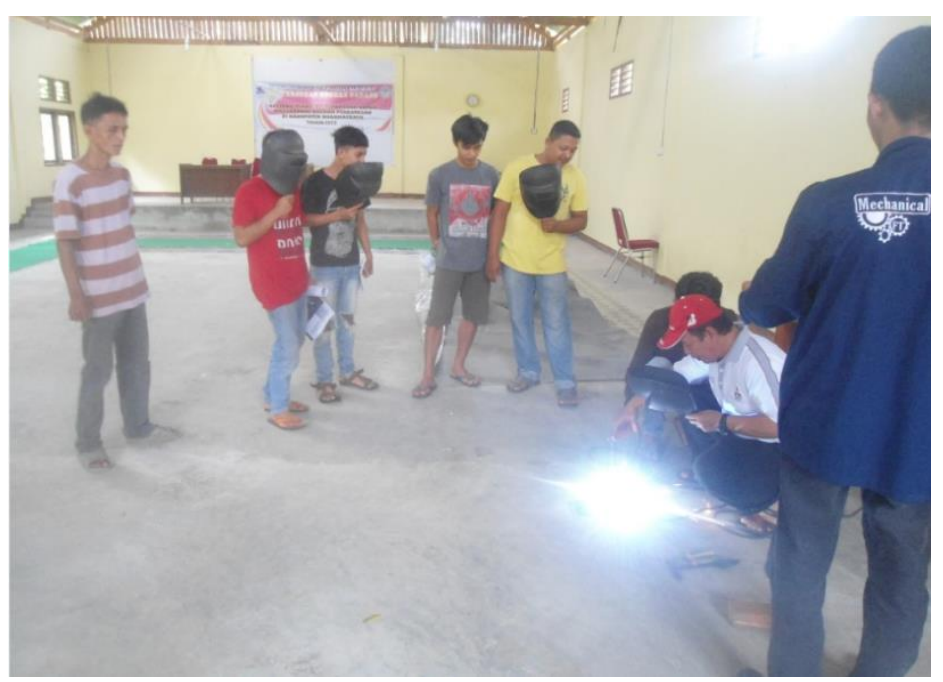

Fig. 8 . The lecturer immediately practised welding techniques on the media 


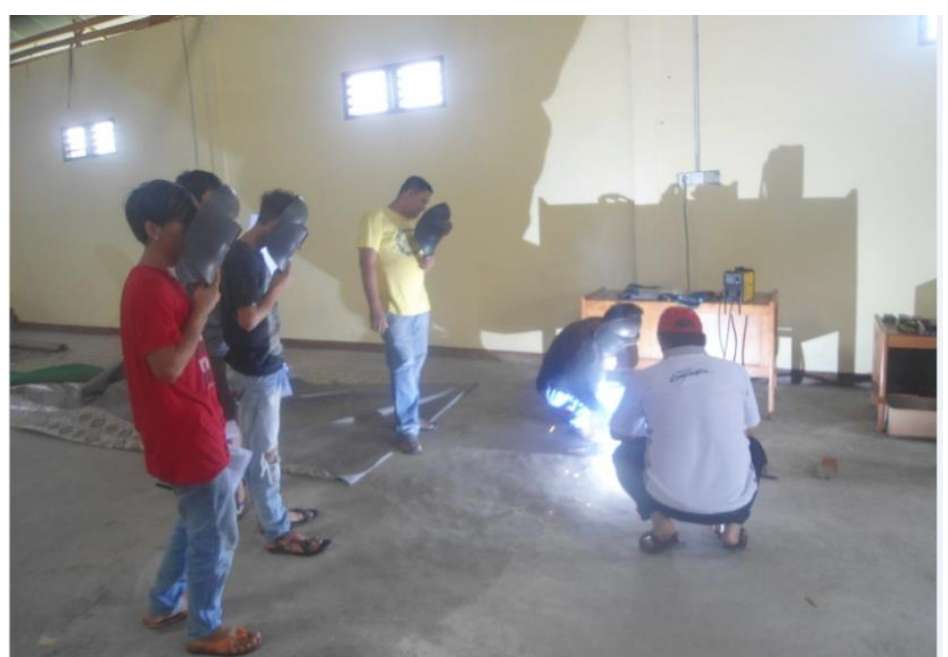

Fig. 9. One of the participants practised welding guided by the lecturer

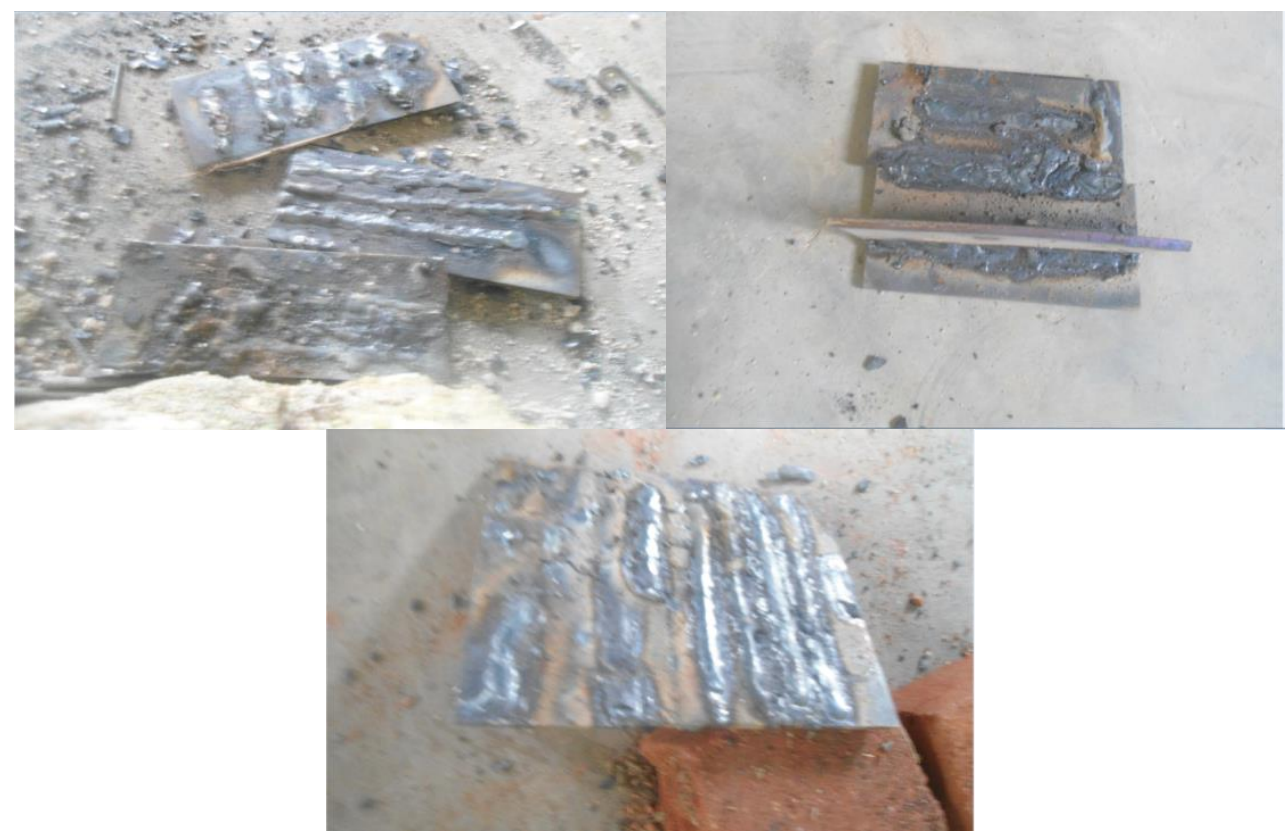

Fig. 10. Welding results of the participants on the first day

On the second day, the speakers began to invite participants to design products that could be made through welding activities in accordance with the needs of the community. In this activity, TIM directs to make a cage. TEAM began to guide participants in the process of making cages. 


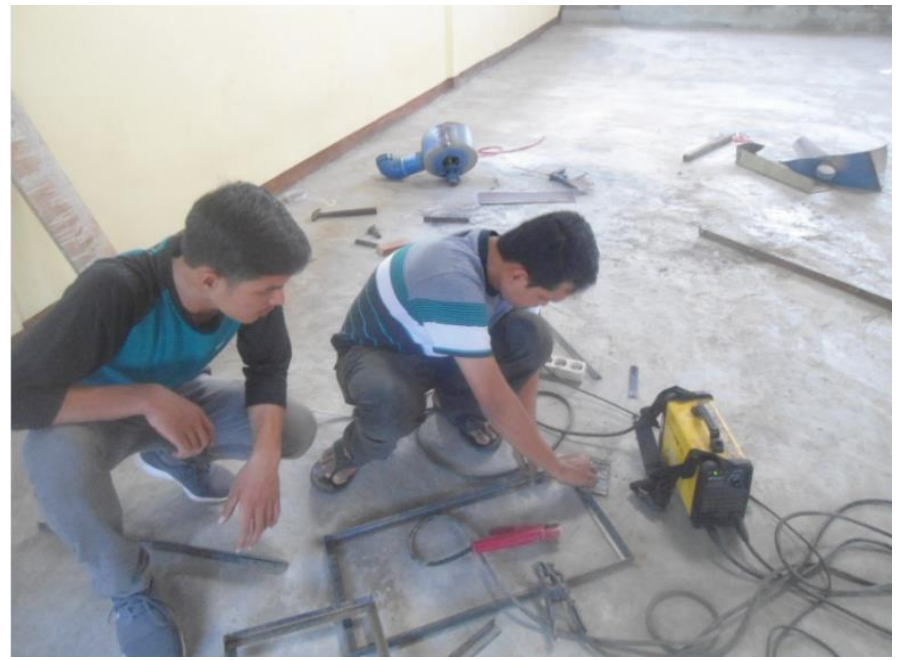

Fig. 11. The team designs and is noticed by the participants

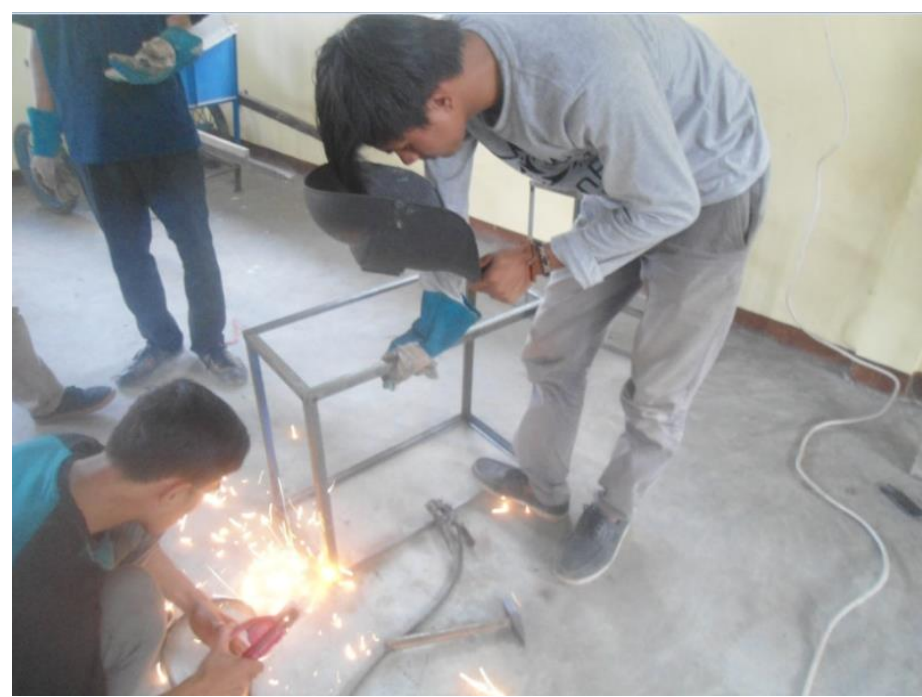

Fig. 12. The team guides participants in making products

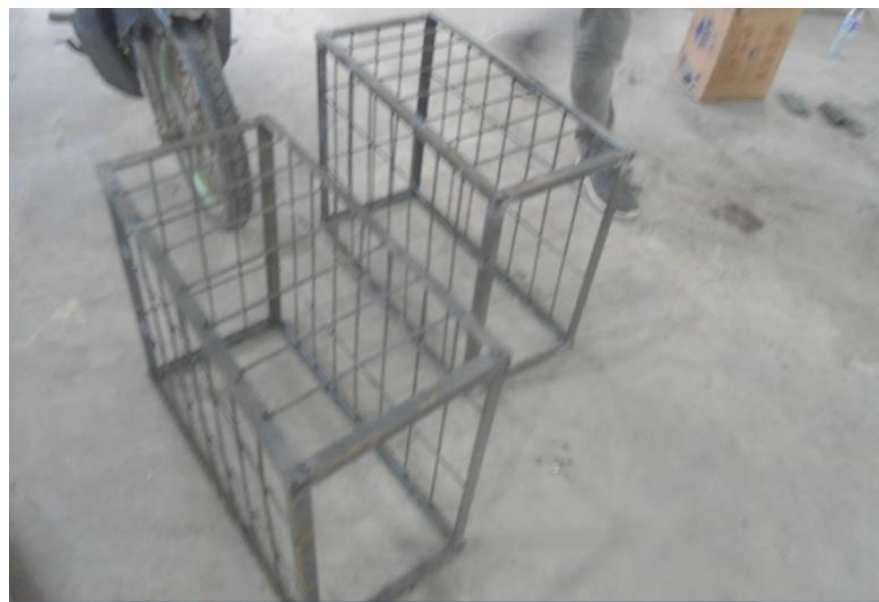

Fig. 13. Semi-finished products 


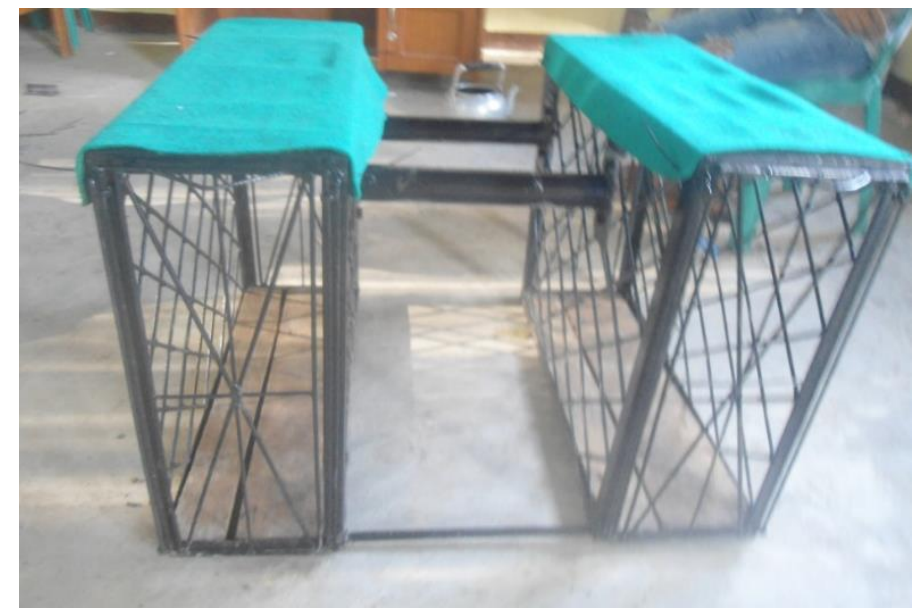

Fig. 14. The final product

On the third day, the TEAM provided direction on how to welding entrepreneurial opportunities. The head of the service with TIM asked the kenagarian to be able to accommodate the birth of new entrepreneurs for youth who could make independent and productive people

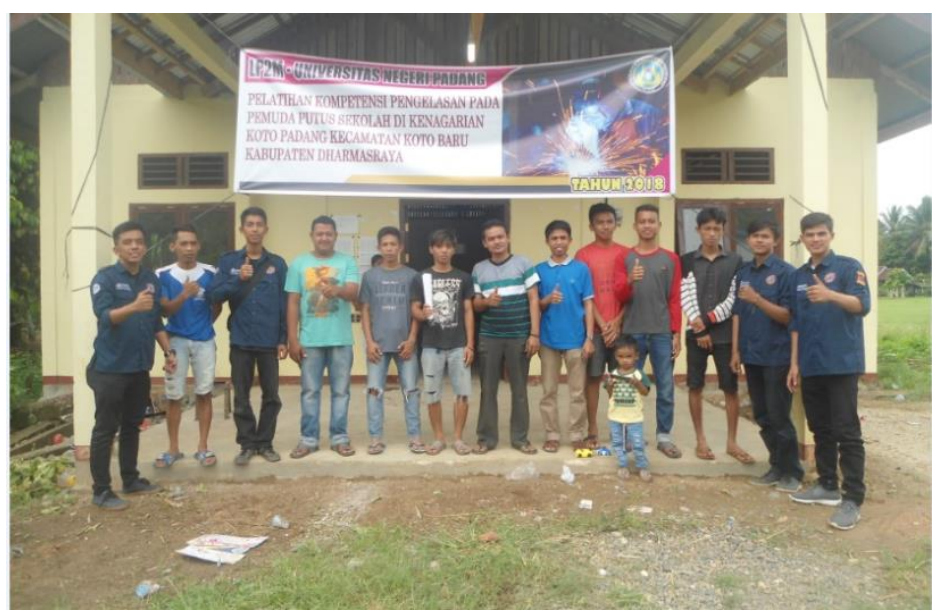

Fig. 15. Group photos after the welding competency training ends

\section{CONCLUSION}

The selection of the right method will make the objectives of the service activities achievable. He uses of modules in community service activities will help drop out students in understanding the basic concepts in the field of welding. Training activities designed based on the needs and manufacture of products stimulate youth to become entrepreneurs.

\section{REFERENCES}

[1] Daswir, dan I. Kusuma., Sistem Usaha tani gambir di Sumatera Barat, Media Komunikasi Penelitian dan Pengembangan Tanaman Industri, 1993; 11: 68-74

[2] Musfiqon. Sosiologi Pendidikan: Suatu Analisis Sosiologi Tentang Pelbagai Problem Pendidikan. Jakarta: Rineka cipta. 1993

[3] Gunarm D, Singgih., Model Pendidikan Kewirausahaan Berbasis Ketrampilan Lokasi Bagi Anak Putus Sekolah Pada Masyarakat Marginal, Jurnal Cakrala Pendidikan. 2004.

[4] Abdul Munir. Masalah Sosial Anak. Jakarta: Kencana Prenada Media Grup. 2004.

[5] Abdussalam. R. Perkembangan \& Pertumbuhan Peserta Didik. Bandung: CV Andi Offset. 1990

[6] Lusiana eva.R.P., Studi Kasus Tentang Anak Putus Sekolah di Kecamatan Moutoung, Jurnal Pendidikan Ilmu Pengetahuan Sosial". Fakultas Keguruan dan Ilmu Pendidikan Universitas Tadulako.

[7] David W. Kaplan., Cause of Student Absenteeism and School Dropouts". Internasional Journal of Intructione-ISSN, 1990 : (9) 1 : 1308-1470 
[8] Merry elike evelyin titaley., Analisis Faktor-Faktor Penyebab Anak Putus Sekolah Usia Pendidikan Dasar Di Kecamatan Gerokgrak Tahun 2012/2013, Jurnal penelitian Universitas Pendidikan Ekonomi Ganesa Singaraja, 2014; 4 (1)

[9] Maulana. Badan Pusat Statistik (BPS). 2017. [Online] Tersedia: http://www.bps.go.id/ [Diakses pada 2 Februari 2018 pada jam 20.20 WIB]

[10] Kementrian Pendidikan dan Kebudayaan. UNICEF Indonesia. Bandung: Lembaga Penelitian SMERU. 2012 